\title{
A Study on Milk Yield, Fertility and Milk Quality Characteristics of Primiparous Red-Holstein and Holstein-Friesian Cows
}

\author{
Atakan Koç ${ }^{1, a, *}$, Ramazan Gürses ${ }^{2, b}$ \\ ${ }^{I}$ Department of Animal Science, Faculty of Agriculture, Aydin Adnan Menderes University, 09100 Aydin, Turkey \\ *Corresponding author

\begin{tabular}{l|l}
\hline A R T ICLE INFO & A B S T R A C T \\
\hline & The aim of this study was to determine the reproductive characteristics, milk yield and milk quality
\end{tabular} \\ Research Article \\ of Primiparous Red-Holstein (RH) and Holstein-Friesian (HF) cows. For this aim, records and \\ monthly taken milk samples of $83 \mathrm{RH}$ and $14 \mathrm{HF}$ raised on a farm in Aydın, Turkey were used. The \\ averages of the first calving age (FCA), gestation length (GL), days open (DO), calving interval (CI), \\ Received : 17/06/2020 \\ Accepted : 04/10/2020 \\ daily milk yield (DMY), 305-day milk yield (305-dMY), solid non-fat (SNF) and $\log _{10}$ somatic cell \\ count $\left(\log _{10} \mathrm{SCC}\right)$ of milk were found to be $27.6 \pm 0.24 \mathrm{mo}, 278.4 \pm 1.09 \mathrm{~d}, 144.0 \pm 7.12 \mathrm{~d}, 421.4 \pm 7.66$ \\ $\mathrm{d}, 22.7 \pm 0.21 \mathrm{~kg}, 6981 \pm 137.0 \mathrm{~kg}, 9.8 \pm 0.04 \%$ and $4.59 \pm 0.024$ (38905 cells $/ \mathrm{ml})$, respectively. Except \\ for DMY, the differences between the breeds were statistically insignificant for FCA, GL, DO, CI, \\ 305-dMY, SNF and $\log _{10}$ SCC. DMY averages for RH and HF were $21.8 \pm 0.21 \mathrm{~kg}$ and $24.3 \pm 0.49 \mathrm{~kg}$, \\ respectively. The effect of season on FCA and the effect of lactation month on SNF and $\log _{10} \mathrm{SCC}$ \\ were also found to be statistically significant. Apart from DMY, not any significant difference was

\section{İlk Laktasyondaki Kırmızı-Alaca ve Siyah-Alaca Sığırlarda Süt ve Döl Verimi ile Süt Kalite Özellikleri Üzerine Bir Araştırma}

\begin{tabular}{|c|c|}
\hline M A K A L E B İ L G İ S İ & Ö Z \\
\hline $\begin{array}{l}\text { Anahtar Kelimeler: } \\
\text { Süt sığırı } \\
\text { Döl verimi } \\
\text { Süt verimi } \\
\text { Süt Kalitesi } \\
\text { Somatik hücre sayıs1 }\end{array}$ & 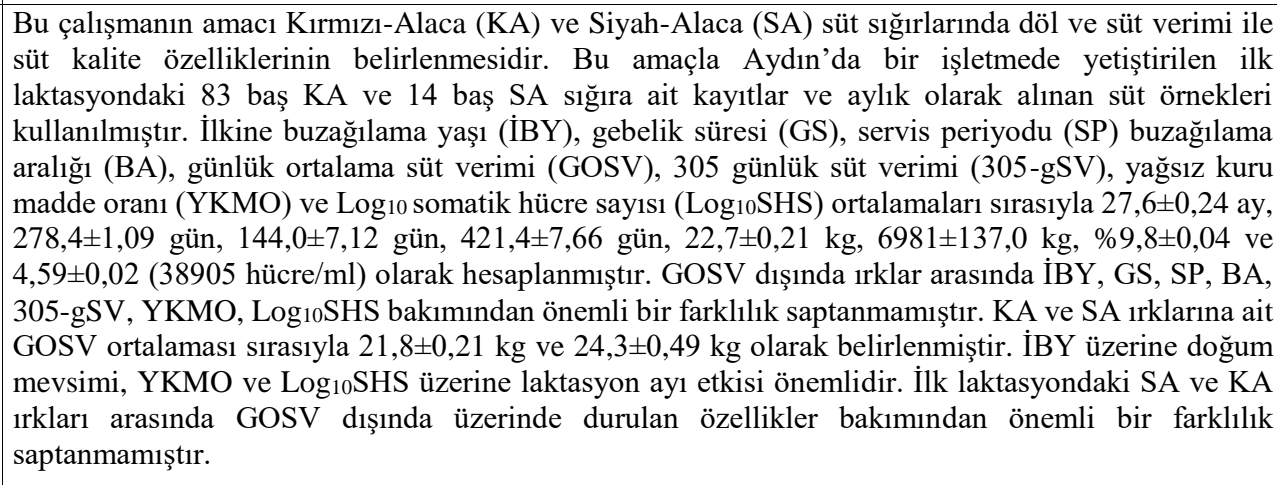 \\
\hline
\end{tabular}




\section{Introduction}

Cattle was domesticated about 10-12 thousand years ago to benefit from the pulling power in field agriculture, and it made the important contributions to humanity with milk, meat and leather productions. In recent years, one of the preferred breeds by Turkish dairy cattle farmers have been Red-Holstein (RH) and the number of studies conducted on the yield characteristics and milk quality of this breed in Turkey is very limited.

$\mathrm{RH}$, which has recessive homozygous ( $\mathrm{rr}$ ) in terms of color gene, are red and white in color. The USA, Canada and some European countries formed a separate pedigree for RH and accepted it as a separate breed from HolsteinFriesian (HF) in the 1950s (Y1lmaz, 2010).

In studies on fertility characteristics of RH breed in the conditions of Turkey, the average first calving age (FCA) was reported to be $851.6 \pm 6.19 \mathrm{~d}(28.4 \mathrm{mo}, \mathrm{n}=181)$ by Koc et al. (2011), $874.8 \pm 13.72 \mathrm{~d}(29.2 \pm 0.32 \mathrm{mo} ; \mathrm{n}=316)$ by Koç et al. (2017) and $842.4 \pm 21.04 \mathrm{~d}(28.1 \mathrm{mo}, \mathrm{n}=38)$ by Koç (2017a). No studies on DO average have been found in the conditions of Turkey. The mean of calving interval (CI) for $\mathrm{RH}$ was reported to be $445.3 \pm 4.69 \mathrm{~d}(\mathrm{n}=322)$ by Koç et al. (2011) and $443.0 \pm 4.90 \mathrm{~d}(\mathrm{n}=286)$ by Koç (2012). Mean GL of the breed was reported as $278.8 \pm 0.28 \mathrm{~d}$ (Koç et al., 2011).

Milk yield mean obtained per milking of the breed was reported between $9.8 \pm 0.46 \mathrm{~kg}$ and $12.2 \pm 0.46 \mathrm{~kg}$ by Y1lmaz (2010), $11.6 \pm 0.22 \mathrm{~kg}$ in morning milking and $10.2 \pm 0.21 \mathrm{~kg}$ in evening milking by Koç (2015) and $12.8 \pm 0.01 \mathrm{~kg}$ and $11.1 \pm 0.01 \mathrm{~kg}$ for morning and evening milking respectively by Koç (2017b). The average 305-dMY of the breed was also reported as $7652.8 \pm 80.68 \mathrm{~kg}$ (Y1lmaz, 2010).

In the studies on milk quality characteristics of the breed, Yilmaz (2010) reported SNF as $8.9 \pm 0.07 \%$, Koç (2015) determined $8.6 \pm 0.04 \%$ and $8.6 \pm 0.04 \%$ in the morning and evening milking, respectively.

In a study conducted by Koç (2015) in a RH herd in Aydın, Turkey, from 449 samples taken in the morning and 442 samples taken in the evening milking, the means of SCC were determined as 91833 cells / $\mathrm{ml}$ and 100462 cells $/ \mathrm{ml}$, respectively. In the same study, the SCC mean of the breed in the first lactation was 54702 cells / $\mathrm{ml}$ and lower than all other parities.

In this study, the fertility, first lactation milk yield and milk quality characteristics of $\mathrm{HF}$ and $\mathrm{RH}$ which have been preferred as an alternative to HF breed in recent years, brought from Germany to a farm in Koçarlı commune of Aydin, Turkey, were investigated.

\section{Material and Method}

The animal material of the study consisted of $83 \mathrm{RH}$ and $14 \mathrm{HF}$ cows in the first lactation, which were brought from Germany in 2015 and calved in late 2015 and early 2016 in a dairy cattle farm located in Cincin county of Koçarlı commune, Aydın, Turkey. In addition to the fertility and milk yield records, milk samples were collected from these cows 10 times for one visit per month at milking times. In this study, only the data of the cows in the first lactation were used.
By using the records of the cattle in the establishment and the records of Aydin Cattle Breeders Association, information such as birth date, insemination date, calving date belonging to the animals were obtained, and FCA, GL, DO and CI characteristics of the animals were determined.

Records of milk yield of cows were provided by visiting the farm once a month (one month at the morning milking, the next month at the evening milking). Daily milk yield (DMY) was calculated by multiplying the amount of milk given by the animal during the operation visit by two (Kumlu, 2008). Using these yields, 305-dMY of the cows were calculated according to Holland method (Gönül, 1971).

Milk samples were taken before milking after the prestimulation of the udder, and 2-3 strips of milk from each teat were milked and then the milk samples were taken in $50 \mathrm{ml}$ plastic tubes and kept in an iced box before analysis. The samples were analyzed to determine the SNF and SCC at ADU Faculty of Agriculture, Department of Animal Breeding and Improvement Laboratory. SNF was determined with a refractometer (FG-103 Brix 0-32\%). For SCC analysis, Direct Microscopic Somatic Cell Counting Method was used. By using a micropipette, $10 \mu \mathrm{lmilk}$ spreads on a strip area of $1 \mathrm{~cm}^{2}$ on a slide and kept until spread milk dried to fix the cells. The cells were colored with a methylene blue colorant and before counting the cells, the slide was dried and washed with water to take out the excess of colorant.

\section{Statistical Analysis}

All cows were almost at the same lactation period because they calved in late 2015 and early 2016 and the number of cows from both breeds were enough to be compared. Since the number of HF cows is not very large, the effects of individual differences regarding the traits emphasized on the average might be high. In order to ensure homogeneity of variance in SCC data, values were transformed using ten base logarithms $\left(\log _{10}\right)$ before statistical analysis.

In the statistical analysis of the data, SAS (1999) package program was used and the differences between the groups were determined according to Tukey $(\mathrm{P}<0.05)$ multiple comparison test. The following statistical model was used in the analysis of FCA, DO, CI and 305-dMY:

$$
\mathrm{y}_{\mathrm{ijk}}=\mu+\mathrm{a}_{\mathrm{i}}+\mathrm{b}_{\mathrm{j}}+\mathrm{e}_{\mathrm{ijk}}
$$

Where;

$\mathrm{y}_{\mathrm{ijk}}$ : Observed value of the trait,

$\mu$ : overall mean,

$\mathrm{a}_{\mathrm{i}}$ : breed effect ( $\mathrm{i}=\mathrm{RH}$ and HF)

$b_{j}$ : Birth season effect for FCA $(j=$ spring, summer and autumn, there was not any record for winter), calving month effects for DO and CI $(\mathrm{j}=8$., 9., and 12. mo), FCA group effects for 305-dMY $(j=<24$ mo, 24-27 mo, 28-30 mo and >30 mo)

$\mathrm{e}_{\mathrm{ijk}}$ : Random error. 
For the statistical analysis of GL, the following model was used:

$$
y_{i j}=\mu+a_{i}+e_{i j}
$$

Where;

$$
\begin{array}{ll}
\mathrm{y}_{\mathrm{ij}} & : \text { Observed value of the trait } \\
\mu & \text { : Overall mean, } \mathrm{a}_{\mathrm{i}}: \text { breed effect (i=RH and HF) } \\
\mathrm{e}_{\mathrm{ij}} & : \text { Random error. }
\end{array}
$$

For the statistical analysis of DMY, SNF and SCC, the following model was used:

$$
y_{i j k}=\mu+a_{i}+b_{j}+(a b)_{i j}+e_{i j k}
$$

Where;

$$
\begin{array}{ll}
\mathrm{y}_{\mathrm{ijk}} & : \text { Observed value of the trait } \\
\mu & : \text { Overall mean } \\
\mathrm{a}_{\mathrm{i}} & : \text { Breed effect }(\mathrm{i}=\mathrm{RH} \text { and } \mathrm{HF}) \\
\mathrm{b}_{\mathrm{j}} & : \text { Lactation month effects }(\mathrm{j}=1,2, \ldots, 11) \\
(\mathrm{ab})_{\mathrm{ij}} & : \text { Breed } \mathrm{x} \text { lactation month interaction effects } \\
\mathrm{e}_{\mathrm{ijk}} & : \text { Random error. }
\end{array}
$$

\section{Results and Discussion}

\section{Fertility Traits}

First calving age (FCA): The breed effect on FCA was insignificant $(\mathrm{P}>0.05)$, however the effect of birth season was important $(\mathrm{P}<0.01)$. FCA means for $\mathrm{RH}$ and $\mathrm{HF}$ were $832.3 \pm 4.82 \mathrm{~d}$ and $818.8 \pm 11.14 \mathrm{~d}$, respectively (Table 1 ). For the spring, summer and autumn, the averages of FCA were calculated as $913.4 \pm 10.04 \mathrm{~d}, 825.8 \pm 7.02 \mathrm{~d}$ and $737.4 \pm 9.38 \mathrm{~d}$, respectively, and the differences between all birth seasons were important $(\mathrm{P}<0.01)$.

While FCA average of animals born in autumn was 176 days shorter than those born in the spring, the animals born in the summer had 87.57 days shorter FCA than those born in the spring, and 88.43 days longer than those born in autumn $(\mathrm{P}<0.01)$.

FCA average of the animals born in autumn was 24.58 mo, which was considered ideal as 24-25 mo. This value showed that the animals were inseminated at an age of about 15 mo. However, it was understood that the animals born in the spring and summer months conceived by being inseminated at the age of approximately $21 \mathrm{mo}$ and $18 \mathrm{mo}$, respectively. Since these animals were brought being heifers from Germany, it was understood that the animals could not reach the desired live weight at the age of 15-16 mo and therefore, their first insemination was delayed considering that the animals were mainly grazed on pasture.

In this study, the average FCA found for RH breed $(832.3 \pm 4.82 \mathrm{~d})$ was about 15 days higher than the result reported by Koç (2017a) for the same breed, and the average of $818.8 \pm 11.14 \mathrm{~d}$ obtained in this study for HF breed was 23.7 days shorter than the result reported by the same author.

The averages of FCA for HF and RH breeds found in this study were shorter than the results reported by Perez et al. (1986) for HF, Speignt and Fairline (1987) for HF, Gyawu et al. (1990) for HF, Şekerden et al. (1989) for HF, Koç (2011) for HF and Montbeliarde breeds, Koç et al. (2011) for RH, Koç (2016) for RH and SIM breeds and Koç et al. (2017) for HF, RH and Simmental (SIM) breeds, but very close to the results of Nenadovic et al. (1987) for HF and Koç (2001) for HF. Similarly, to this study, Koç et al. (2011) reported about one month longer FCA in summer born animals than those born in winter.

Gestation Length $(G L)$ : GL mean values of $\mathrm{RH}$ and $\mathrm{HF}$ are given in Table 2. GL means of the breeds were $278.22 \pm 1.189 \mathrm{~d}$ and $279.38 \pm 2.911 \mathrm{~d}$, respectively and the difference between the breeds was not significant $(\mathrm{P}>0.05)$. In this study, the GL means for RH and HF breeds were higher than the average reported by Duranl1 (2008) for HF breed $(285.1 \pm 1.66 \mathrm{~d})$, and similar to the average (278.8 $\pm 0.28 \mathrm{~d})$ reported by Koç et al. (2011) for RH.

Days Open (DO) and Calving Interval (CI): The effects of breed and calving month on DO and CI were insignificant $(\mathrm{P}>0.05)$. DO values of $\mathrm{RH}$ and $\mathrm{HF}$ ranged from $36 \mathrm{~d}$ to $373 \mathrm{~d}$, with an overall average of $144.0 \pm 7.12$ d. CI values changed between $319 \mathrm{~d}$ and $646 \mathrm{~d}$ and the average was calculated as $421.4 \pm 7.66 \mathrm{~d}$ (Table 3 ).

The means of DO for RH and HF breeds were $136.3 \pm 10.33 \mathrm{~d}$ and $127.6 \pm 21.54 \mathrm{~d}$, and the means for CI were $409.1 \pm 10.95 \mathrm{~d}$ and $409.1 \pm 23.46 \mathrm{~d}$, respectively. According to the calving month, the shortest DO average was obtained for August with 109.4 $\pm 35.79 \mathrm{~d}$, while the longest was obtained for October with $158.6 \pm 12.7 \mathrm{~d}$. The difference of $49.19 \mathrm{~d}$ between these two months was insignificant $(\mathrm{P}>0.05)$. While DO average showed a steady increase from August to October, it decreased from October to December.

A similar situation was observed for CI trait. The average CI, which was $380.5 \pm 37.98 \mathrm{~d}$ in August, increased to $442.0 \pm 13.97 \mathrm{~d}$ in September and decreased to $397.0 \pm 31.72 \mathrm{~d}$ in December. The $61.5 \mathrm{~d}$ difference between the lowest CI average in August and the highest in October was statistically not significant $(\mathrm{P}>0.05)$.

In this study, the means of DO found for RH $(136.3 \pm 10.33$ d) and HF (127.6 $\pm 21.54 \mathrm{~d})$ were longer than the results reported for HF breed by Özçelik and Arpacık (2000), Duru and Tuncel (2002a), Türkyılmaz (2005), Juozaitiene and Juozaitis (2005), similar to the results reported for HF cows born in Turkey but shorter than HF cows brought from Italy as stated by Uzmay et al. (1998), and similar to the means of the fourth and sixth parities but, longer than the other parities reported for HF by Yaylak (2003).

When the situation for CI trait was evaluated, CI means for RH (409.1 $\pm 10.95 \mathrm{~d})$ and HF $(409.1 \pm 23.46 \mathrm{~d})$ found in this study were shorter than the results reported for HF (391.8 \pm 1.45 d) by Koç (2001), for HF (399.6 \pm 5.93 d) and Montbeliarde (391.6 \pm 5.75 d) breeds by Koç (2011), for RH $(445.3 \pm 4.69 \mathrm{~d})$ by Koç et al. (2011), and for RH (443 \pm 4.9 d) by Koç (2012).

In this study, it can be interpreted that DO and CI averages calculated for RH and HF breeds were longer than the ideally accepted periods. The owner of the farm might let delay the insemination of the cows because they were in the first lactation and thus their growth continued.

\section{Milk Yield and Quality Traits}

Daily Milk Yield (DMY): DMY values of RH and HF breeds varied between $4.7 \mathrm{~kg}$ and $36.6 \mathrm{~kg}$, with an overall average of $22.7 \pm 0.21 \mathrm{~kg}$. The effects of breed and lactation month on DMY were statistically significant $(\mathrm{P}<0.01)$, but the interaction effect of breed $\mathrm{x}$ lactation month was insignificant $(\mathrm{P}>0.05)$. DMY averages of HF and RH were found to be $24.3 \pm 0.49 \mathrm{~kg}$ and $21.8 \pm 0.21 \mathrm{~kg}$, respectively. 
The difference of $2.5 \mathrm{~kg}$ found between breeds was statistically significant $(\mathrm{P}<0.01)$. DMY averages of the second, third and fourth lactation months was above 26.0 $\mathrm{kg}$. After the fifth month, the average decreased gradually towards the end of lactation, and the value in the last month was $15.7 \pm 0.99 \mathrm{~kg}$ (Table 4).

It is known that while their persistency is high, the cows at the first parity produce lower milk than the cows at higher parities. The lower milk yield drop rate found for the animals in this study may be attributed to their first lactation, in other words, their higher persistency rate.

The DMY averages found in this study for HF and $\mathrm{RH}$ breeds were higher than the means reported by Koç (2008a) for HF and by Koç et al. (2009) for HF and RH. In this study, since milk measurement is made as alternate, one month in the morning and the next month in the evening, when half of DMY average is accepted as inspection time milk yield (ITMY), the averages for HF and RH breeds can be calculated as 12.1 and $10.9 \mathrm{~kg}$, respectively. In this case, ITMY obtained for HF breed is lower than the average reported by Koç (2007a), and higher than the values reported by Koç (2007b) and by Koç (2011) for HF breed.

In this study, the average ITMY calculated for RH (10.9 $\mathrm{kg}$ ) was lower than the average reported by Y1lmaz (2010) for RH cows in the morning milking in winter and in the morning and evening milking times in summer, however, it was higher than the average obtained in the evening milking in winter $(9.9 \pm 0.46 \mathrm{~kg})$, and higher than the values reported by Koç (2017b) for RH in the morning and evening milking times.

Also, in this study, the average ITMY calculated for RH was lower than the values reported for the first lactating cows of RH $(11.2 \pm 0.25 \mathrm{~kg})$ by Koç (2015). The average ITMY calculated in this study for both RH and HF breeds were higher than the values reported for Montbeliarde cows by Koç (2007a), for Brown-Swiss (BS) cows by Koç (2007b), and for Montbeliarde cows reported by Koç (2011).

In this study, both DMY and ITMY averages obtained for $\mathrm{HF}$ and $\mathrm{RH}$ breeds were lower than the averages reported for the same breeds in some other studies conducted in the same region before, because all the cows in this study were at the first lactation, as a result of that, they produced physiologically less milk than the cows at higher parities.

The changes of DMY for RH and HF breeds according to the lactation months are given on Figure 1. As seen on the figure, except the second lactation month, in all month's HF breed had a higher DMY than RH breed. In both breeds, the mean DMY also decreased significantly in the $9^{\text {th }}, 10^{\text {th }}$ and $11^{\text {th }}$ months because they were at the late stage of lactation.

Table 1. The first calving age (FCA) least squares means and standard errors

\begin{tabular}{|c|c|c|c|c|c|c|c|}
\hline \multirow{2}{*}{ Factor } & \multirow{2}{*}{$\mathrm{n}$} & \multicolumn{3}{|c|}{$\overline{F C A}(\mathrm{~d})$} & \multicolumn{3}{|c|}{ FCA (mo) } \\
\hline & & $\bar{X} \pm S_{\bar{X}}$ & $\min$ & $\max$ & $\bar{X} \pm S_{\bar{X}}$ & $\min$ & $\max$ \\
\hline Breed & & $\mathrm{NS}$ & & & NS & & \\
\hline RH & 82 & $832.3 \pm 4.82$ & 663 & 1008 & $27.7 \pm 0.16$ & 22.1 & 33.6 \\
\hline $\mathrm{HF}$ & 14 & $818.8 \pm 11.14$ & 677 & 934 & $27.3 \pm 0.37$ & 22.6 & 33.1 \\
\hline Calving Season & & $* *$ & & & $* *$ & & \\
\hline Spring & 20 & $913.4 \pm 10.04^{\mathrm{a}}$ & 821 & 1008 & $30.4 \pm 0.33^{\mathrm{a}}$ & 27.4 & 33.6 \\
\hline Summer & 54 & $825.8 \pm 7.02^{\mathrm{b}}$ & 735 & 901 & $27.2 \pm 0.23^{\mathrm{b}}$ & 24.5 & 30.0 \\
\hline Autumn & 22 & $737.4 \pm 9.38^{c}$ & 663 & 797 & $24.6 \pm 0.31^{\mathrm{c}}$ & 22.1 & 26.6 \\
\hline Overall & 96 & $828.2 \pm 7.25$ & 663 & 1008 & $27.6 \pm 0.24$ & 22.1 & 33.6 \\
\hline
\end{tabular}

RH: Red Holstein, HF: Holstein Friesian, NS: not significant, **: significant for P<0.01, a,b,c: The difference between groups with the same letter is insignificant for $\mathrm{P}<0.05$.

Table 2. Gestation length (GL) least squares means and standard errors of Red Holstein (RH) and Holstein-Friesian (FH) cows

\begin{tabular}{l|cccc}
\hline \multirow{2}{*}{ Factor } & \multicolumn{4}{c}{ GL (d) } \\
\cline { 2 - 5 } & $\mathrm{n}$ & $\bar{X} \pm S_{\bar{X}}$ & min & max \\
\hline Breed & & NS & 252 & 301 \\
RH & 78 & $278.2 \pm 1.19$ & 254 & 286 \\
HF & 13 & $279.4 \pm 2.91$ & 252 & 301 \\
\hline Overall & 91 & $278.4 \pm 1.09$ & & \\
\hline NS:
\end{tabular}

NS: not significant

Table 3. Days open (DO) and calving interval (CI) least squares means and standard errors of Red Holstein (RH) and Holstein-Friesian (HF) cows

\begin{tabular}{|c|c|c|c|c|c|c|c|c|}
\hline \multirow{2}{*}{ Factor } & \multicolumn{4}{|c|}{$\mathrm{DO}(\mathrm{d})$} & \multicolumn{4}{|c|}{$\overline{C I}(\mathrm{~d})$} \\
\hline & $\mathrm{n}$ & $\overline{\bar{X}} \pm S_{\bar{X}}$ & $\min$ & $\max$ & $\mathrm{n}$ & $\overline{\bar{X}} \pm S_{\bar{X}}$ & $\min$ & $\max$ \\
\hline Breed & & $\overline{\mathrm{NS}}$ & & & & $\overline{N S}$ & & \\
\hline RH & 79 & $136.3 \pm 10.33$ & 36 & 373 & 78 & $409.1 \pm 10.95$ & 319 & 646 \\
\hline $\mathrm{HF}$ & 13 & $127.6 \pm 21.54$ & 36 & 258 & 12 & $409.1 \pm 23.46$ & 320 & 538 \\
\hline Calving Month & & NS & & & & NS & & \\
\hline 8 & 4 & $109.4 \pm 35.79$ & 71 & 172 & 4 & $380.5 \pm 37.98$ & 326 & 456 \\
\hline 9 & 14 & $141.7 \pm 19.25$ & 55 & 258 & 14 & $416.4 \pm 20.44$ & 321 & 538 \\
\hline 10 & 37 & $158.6 \pm 12.74$ & 36 & 373 & 36 & $442.0 \pm 13.97$ & 320 & 646 \\
\hline 11 & 31 & $126.8 \pm 15.34$ & 36 & 201 & 30 & $409.5 \pm 16.57$ & 319 & 471 \\
\hline 12 & 6 & $123.0 \pm 29.85$ & 86 & 186 & 6 & $397.0 \pm 31.72$ & 333 & 459 \\
\hline Overall & 92 & $144.0 \pm 7.12$ & 36 & 373 & 90 & $421.4 \pm 7.66$ & 319 & 646 \\
\hline
\end{tabular}

NS: not significant 
305-Day Milk Yield (305-dMY): Breed and FCA group effects on the 305-dMY of the cattle raised in the farm were found insignificant $(\mathrm{P}>0.05)$, and the overall average of $305-\mathrm{dMY}$ was calculated as $6981 \pm 137.0 \mathrm{~kg}$. The averages of 305-dMY for RH and HF breeds were calculated as $6785.1 \pm 163.54 \mathrm{~kg}$ and $7344.6 \pm 335.95 \mathrm{~kg}$, respectively (Table 5). Although HF produced $599.5 \mathrm{~kg}$ higher milk than $\mathrm{RH}$, this difference was statistically insignificant ( $\mathrm{P}>0.05)$. The average of 305-dMY in RH ranged between $3883 \mathrm{~kg}$ and $9784 \mathrm{~kg}$, and in HF between 6289 and 9270 $\mathrm{kg}$. As FCA increased, 305-dMY increased until the age of 30 months, then decreased in $>30$ months group. The lowest 305-dMY mean was obtained for the oldest age group (Table 5). While the group with an age $>30$ months produced $736.3 \mathrm{~kg}$ lower milk than the group with the age of 28-30 months, the difference was not found to be statistically significant $(\mathrm{P}>0.05)$. The averages of 305dMY for HF and RH breeds calculated in this study are higher than the averages reported for HF and BS breeds raised in the same region by Koç (2006a). Different from this study, Koç (2006a) found the effect of breed on 305dMY was statistically significant.

In this study, the averages of 305-dMY obtained for RH and HF cows were compared to the averages reported for HF in some previous studies and the means for both breeds were higher than the means reported in other studies (Uzmay et al., 1998; Duru and Tuncel, 2002b; Kaya et al., 2003; Erdem et al., 2007; Çakıllı and Güneş, 2007; Koç, 2011). The average of 305-dMY calculated for HF cows is higher than the average reported by Koç (2001) for the same breed, but the averages found in this study for both HF and RH cows were lower than 305-dMY mean reported for RH by Y1lmaz (2010).

Solid Non-Fat (SNF): SNF determined in milk samples of RH and HF cows was calculated as $9.8 \pm 0.04 \%$ (Table 4). The lactation month effect on SNF was important $(\mathrm{P}<0.01)$, but the effects of breed and breed $\mathrm{x}$ lactation month interaction were insignificant $(\mathrm{P}>0.05)$. SNF means for RH and HF breeds were calculated as $9.9 \pm 0.04 \%$ and $9.7 \pm 0.09 \%$, respectively.

As seen on Figure 2, SNF average dropped significantly in the fourth lactation month, when DMY average was high, and this low level preserved in the months 4 to 9 , after that increased again in $10^{\text {th }}$ and $11^{\text {th }}$ lactation months. There was also a noticeable decrease seen after the $8^{\text {th }}$ month of lactation in DMY.

According to the lactation month, the highest SNF average was obtained for the first lactation month $(10.5 \pm 0.26 \%)$ and the lowest was calculated for the $9^{\text {th }}$ month with $9.1 \pm 0.14 \%$ (Table 4 ). While SNF average was over $10 \%$ in the first three lactation months (Figure 2), it was below $10 \%$ in other months. In terms of lactation months, the $4^{\text {th }}, 8^{\text {th }}$ and $9^{\text {th }}$ months differed from the first three lactation months $(\mathrm{P}<0.05)$. In addition, $10^{\text {th }}$ month was different from the $1^{\text {st }}$ and $3^{\text {rd }}$ months, also, $9^{\text {th }}$ month differed from the mean of $11^{\text {th }}$ month.

It can be said that SNF averages of RH and HF cows were generally similar (Figure 3 ). The milk yield decreased in both breeds, especially in the $9^{\text {th }}, 10^{\text {th }}$ and $11^{\text {th }}$ lactation month, but the SNF did not rise in $9^{\text {th }}$ month for both breeds and $10^{\text {th }}$ month for HF. Despite, this low level in SNF in milk these months could be attributed to the last period of the lactation coinciding with the summer months.

The air temperature rises in the summer months where the farm is located in the region, and the highest temperature rises above $40^{\circ} \mathrm{C}$ in many days in June, July and August, and as a result of that creating heat stress for the cows. Under heat stress conditions, while the dry matter intake of the cows decrease, the milk production and at the same time the milk constituents such as fat and protein contents decrease. Thus, it turns out that it is necessary to take some precautions against the heat stress that can be seen in summer in this farm and other farms in the region. As a matter of fact, Koç (2011) reported that SNF was significantly lower in milk samples taken in summer than those taken in the winter period from $\mathrm{HF}$ and Montbeliarde breeds.

Table 4. Least square means and standard errors of daily milk yield (DMY, kg), solid non-fat (SNF, \%) and somatic cell count $\left(\log _{10} \mathrm{SCC}\right)$ for primiparous Red Holstein $(\mathrm{RH})$ and Holstein-Friesian $(\mathrm{HF})$ cows

\begin{tabular}{|c|c|c|c|c|c|c|}
\hline \multirow{2}{*}{ Factor } & \multicolumn{2}{|c|}{ DMY } & \multicolumn{2}{|c|}{ SNF } & \multicolumn{2}{|c|}{$\log _{10} \mathrm{SCC}$} \\
\hline & $\mathrm{n}$ & $\bar{X} \pm S_{\bar{X}}$ & $\mathrm{~N}$ & $\bar{X} \pm S_{\bar{X}}$ & $\mathrm{n}$ & $\bar{X} \pm S_{\bar{X}}$ \\
\hline Breed & & $* *$ & & NS & & NS \\
\hline $\mathrm{RH}$ & 751 & $21.8 \pm 0.21^{\mathrm{a}}$ & 743 & $9.9 \pm 0.04$ & 737 & $4.6 \pm 0.03$ \\
\hline $\mathrm{HF}$ & 134 & $24.3 \pm 0.49^{b}$ & 133 & $9.7 \pm 0.09$ & 134 & $4.7 \pm 0.06$ \\
\hline Lactation month & & $* *$ & & $* *$ & & $* *$ \\
\hline 1 & 47 & $24.7 \pm 1.39^{\mathrm{ab}}$ & 45 & $10.5 \pm 0.26^{\mathrm{ac}}$ & 44 & $4.5 \pm 0.17^{\mathrm{abd}}$ \\
\hline 2 & 74 & $26.2 \pm 0.87^{\mathrm{a}}$ & 73 & $10.2 \pm 0.16^{\mathrm{ac}}$ & 69 & $4.2 \pm 0.11^{\mathrm{a}}$ \\
\hline 3 & 91 & $26.7 \pm 0.80^{\mathrm{a}}$ & 88 & $10.3 \pm 0.15^{\mathrm{a}}$ & 88 & $4.3 \pm 0.10^{\mathrm{a}}$ \\
\hline 4 & 94 & $26.7 \pm 0.77^{\mathrm{a}}$ & 94 & $9.4 \pm 0.14^{\mathrm{bd}}$ & 94 & $4.4 \pm 0.10^{\mathrm{ac}}$ \\
\hline 5 & 94 & $24.8 \pm 0.77^{\mathrm{a}}$ & 94 & $9.7 \pm 0.14^{\mathrm{abd}}$ & 92 & $4.5 \pm 0.10^{\mathrm{ac}}$ \\
\hline 6 & 96 & $24.6 \pm 0.77^{\mathrm{a}}$ & 96 & $9.6 \pm 0.14^{\mathrm{bcd}}$ & 95 & $4.5 \pm 0.09^{\mathrm{ab}}$ \\
\hline 7 & 96 & $23.9 \pm 0.77^{\mathrm{a}}$ & 95 & $9.9 \pm 0.14^{\mathrm{ab}}$ & 95 & $4.9 \pm 0.09^{\text {bde }}$ \\
\hline 8 & 95 & $23.7 \pm 0.77^{\mathrm{a}}$ & 94 & $9.4 \pm 0.15^{\mathrm{bd}}$ & 95 & $4.7 \pm 0.09^{\text {abde }}$ \\
\hline 9 & 88 & $19.5 \pm 0.77^{b}$ & 88 & $9.1 \pm 0.14^{\mathrm{d}}$ & 88 & $4.7 \pm 0.10^{\text {bcde }}$ \\
\hline 10 & 75 & $16.8 \pm 0.84^{b c}$ & 75 & $9.6 \pm 0.15^{\mathrm{bcd}}$ & 75 & $5.1 \pm 0.10^{\mathrm{de}}$ \\
\hline 11 & 35 & $15.7 \pm 0.99^{c}$ & 34 & $10.0 \pm 0.18^{\mathrm{ab}}$ & 36 & $5.2 \pm 0.12^{\mathrm{e}}$ \\
\hline Breed $\times$ Lac. month & & NS & & NS & & NS \\
\hline Overall & 885 & $22.7 \pm 0.21$ & 876 & $9.8 \pm 0.04$ & 871 & $4.59 \pm 0.024$ \\
\hline
\end{tabular}

NS: Not significant, **: Significant for $\mathrm{P}<0.01$, a,b,c,d,e: The difference between the groups with the same letter is insignificant for $\mathrm{P}<0.05$. 
Table 5. Least square means and standard errors of 305-dMY for Red Holstein (RH) and Holstein-Friesian (HF) cows

\begin{tabular}{|c|c|c|c|c|}
\hline \multirow{2}{*}{ Factor } & \multicolumn{4}{|c|}{ 305-d MY (kg) } \\
\hline & $\mathrm{N}$ & $\bar{X} \pm S_{\bar{X}}$ & $\min$ & $\max$ \\
\hline Breed & & NS & & \\
\hline RH & 55 & $6785.1 \pm 163.54$ & 3883 & 9784 \\
\hline $\mathrm{HF}$ & 11 & $7344.6 \pm 335.95$ & 6289 & 9270 \\
\hline FCA group & & NS & & \\
\hline $1(<24 \mathrm{mo})$ & 8 & $6858.3 \pm 406.20$ & 4590 & 9270 \\
\hline $2(24-27 \mathrm{mo})$ & 16 & $7249.6 \pm 297.23$ & 5563 & 8824 \\
\hline $3(28-30 \mathrm{mo})$ & 30 & $7444.0 \pm 236.46$ & 5121 & 9784 \\
\hline $4(>30 \mathrm{mo})$ & 12 & $6707.7 \pm 327.95$ & 3883 & 7866 \\
\hline Overall & 66 & $6981 \pm 137.0$ & 3883 & 9784 \\
\hline
\end{tabular}

NS: Not significant

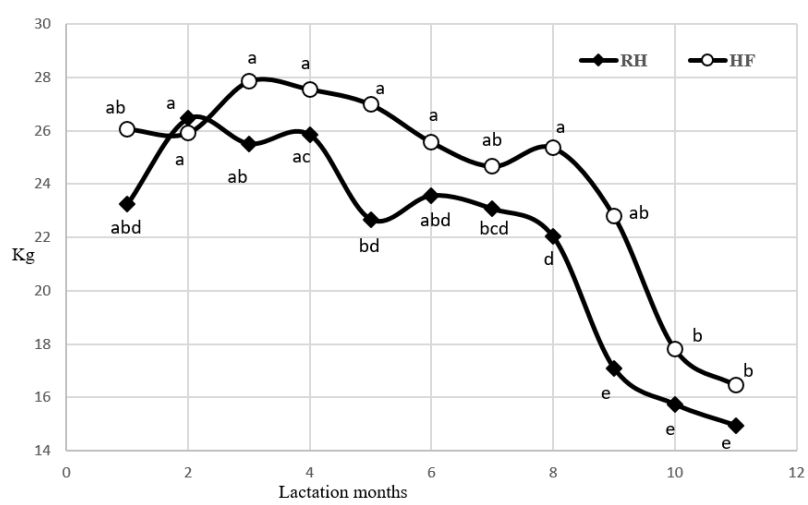

Figure 1. Changes of daily milk yield (DMY) means for RH and HF cows by lactation months.

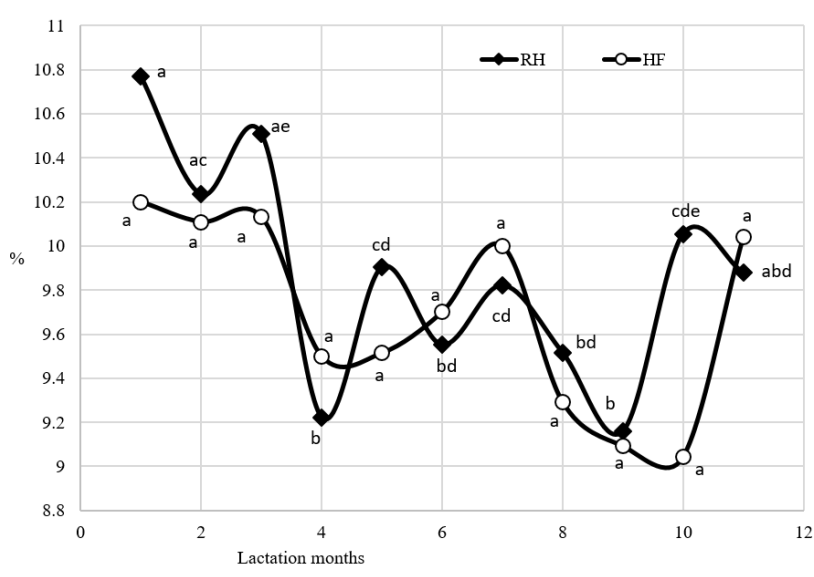

Figure 3. Changes of solid non-fat (SNF, \%) for Red Holstein (RH) and Holstein-Friesian (HF) cows depending on lactation month.

In this study, the averages of SNF obtained for RH and HF cows $(9.9 \pm 0.08 \%$ and $9.7 \pm 0.91 \%$, respectively) were lower than the averages reported by Koç (2007b) for HF and Montbeliarde breeds, and for BS breed by Koç (2007b). However, the averages found for both breeds in this study were higher than the values reported for $\mathrm{HF}$ $(9.6 \pm 0.05 \%)$ by Koç (2007b), for HF $(8.2 \pm 0.07 \%)$ and Montbeliarde $(8.4 \pm 0.07 \%)$ breeds reported by Koç (2011), and higher than the value reported by Koç (2015) for the first lactating RH cows $(8.8 \pm 0.04 \%)$.

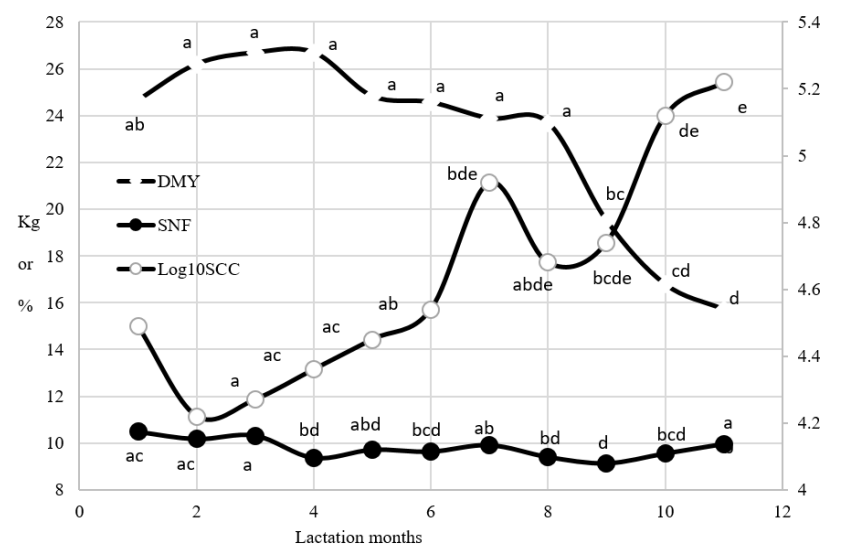

Figure 2. Changes of daily milk yield (DMY), solid non-fat (SNF, \%) and somatic cell count ( $\left.\log _{10} \mathrm{SCC}\right)$ depending on lactation month.

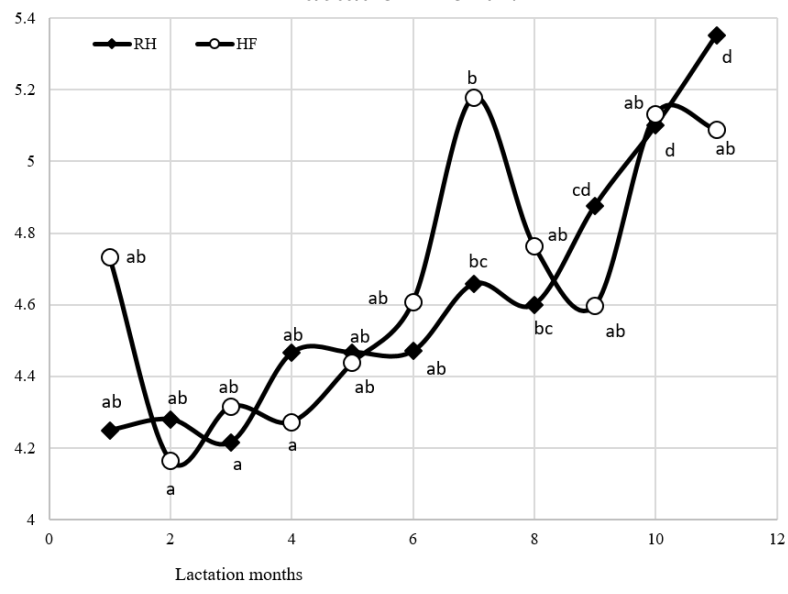

Figure 4. Changes of somatic cell count ( $\log _{10} \mathrm{SHS}$ ) for Red Holstein (RH) and Holstein-Friesian (HF) depending on lactation month.

In this study, SNF average found for HF cows was lower than the average reported by Koç (2008a) for HF $(9.9 \pm 0.02 \%)$. The SNF average obtained in this study for RH cows was higher than the average reported by Y1lmaz (2010) for the primiparous RH cows $(8.9 \pm 0.07 \%)$.

Somatic Cell Count (SCC): The mean of $\log _{10} \mathrm{SCC}$ of cows raised in the farm was $4.59 \pm 0.024$. The lactation month effect on $\log _{10}$ SCC was statistically significant $(\mathrm{P}<0.01)$, but breed and breed $\mathrm{x}$ lactation month interaction effects were insignificant $(\mathrm{P}>0.05)$. $\log _{10} \mathrm{SCC}$ averages for $\mathrm{RH}$ and $\mathrm{HF}$ 
cows were calculated as $4.6 \pm 0.03$ and $4.7 \pm 0.06$, respectively (Table 4).

The changes of DMY, SNF and $\log _{10}$ SCC according to lactation months are given on Figure 2, and the changes of $\log _{10} \mathrm{SCC}$ of $\mathrm{RH}$ and $\mathrm{HF}$ breeds according to lactation months is given in Figure 4. The $\log _{10} \mathrm{SCC}$ average decreased in the second month and increased towards the end of lactation, the increase occurred between the second and seventh lactation months and after a decrease in the eighth month, increased again and reached its highest value in the $11^{\text {th }}$ month (Figure 2). Considering the back-transformed values of $\log _{10} \mathrm{SCC}$, the SCC averages of the last two months of lactation were above 100000 cells / $\mathrm{ml}$, while it was below 50000 cells / $\mathrm{ml}$ in lactation months from 1 to 6 .

The lowest $\log _{10} \mathrm{SCC}$ average occurred in the second lactation month $(4.2 \pm 0.11)$, while the differences in the $7^{\text {th }}$ and $9^{\text {th }}-11^{\text {th }}$ lactation months were insignificant $(\mathrm{P}>0.05)$, the $11^{\text {th }}$ lactation month differs from the months $2^{\text {nd }}-6^{\text {th }}$ and $8^{\text {th }}$ $(\mathrm{P}<0.01)$. It is expected that the SCC value increases towards the end of the lactation and this increase is due to the increase in the density of SCC in the unit volume depending on the decrease in milk yield. Green et al. (2006) examined the milk yield and SCC data both graphically in their study and indicated a dilution effect of milk yield on SCC.

As expected, the mean of $\log _{10} \mathrm{SCC}$ of $\mathrm{RH}$ and $\mathrm{HF}$ increased towards the end of lactation month. Compared to $\mathrm{RH}$, the changes of $\log _{10} \mathrm{SCC}$ mean for lactation months was higher in HF (Figure 4). It can be said that the higher changes in $\log _{10}$ SCC in HF breed is due to the higher effect of some individual differences on the average due to the low number of animals in this breed, compared to RH breed.

The overall low SCC means determined for RH and HF cows may be attributed to the cows being in first parities. Due to the low milk yield of the cows in the first lactation and lower rate to being caught by mastitis, the low level of SCC is an expected condition. In previous studies (Koç, 2008b; 2011; Y1lmaz, 2010), it was revealed that the SCC level increased due to the increase of parity.

In this study, the averages of SCC for HF and RH cows were lower than all other studies used as literature sources in this study, like HF cows raised in four different farms in Aydın province reported by Koç (2006b), for HF and Montbeliarde cows reported by Koç (2007a and 2011), for $\mathrm{HF}$ and BS breeds reported by Koç (2007b), and for HF reported by Koç (2008a, b) and for RH reported by Koç (2015).

In this study, the averages of SCC for RH and HF cows are lower than the average (63753 cells / $\mathrm{ml}$ ) reported by Y1lmaz (2010) for RH cows, but is very close to the average value (47687 cells / $\mathrm{ml}$ ) reported for the same author for the first lactating $\mathrm{RH}$ cows.

\section{Conclusion}

Examination of the fertility, milk yield and milk quality characteristics of RH and HF indicated that except for DMY, not any significant differences were determined between these two breeds raised on the same farm. RH cows produced $2.5 \mathrm{~kg}$ less milk per day than HF cows. Lactation month effects on DMY, SNF and $\log _{10} \mathrm{SCC}$, and birth season effect on FCA was also determined important. Considering that $\mathrm{HF}$ and $\mathrm{RH}$ cows were in the first parity, about $7000 \mathrm{~kg}$ milk yield level can be considered as an indication that these animals could reach higher milk yield levels in later parities. In order to prevent the decrease in the fertility of cows in the farm, more importance should be given to items such as maintenance, feeding, housing and herd management.

\section{References}

Çakıllı F, Güneş H. 2007. Studies on the milk production traits of Brown Swiss cattle. J. Fac. Vet. Med. Istanbul Univ, 33(3): 43-58.

Duranl1 M. 2008. Estimation of Phenotypic and Genetic Parameters of Some Yield Traits of Holstein-Friesian Cows Raised in Koçaş State Farm. PhD Thesis. Graduate School of Natural Science, Selçuk Univ., Konya, Turkey.

Duru S, Tuncel E. 2002a. An investigation on milk yield and reproductive performance of Holstein Friesian cows in Kocas State Farm. 2. Reproductive traits. Türk J. Vet. Anim. Sci. 26:103-107.

Duru S, Tuncel E. 2002b. An investigation on milk yield and reproductive performance of Holstein Friesian cows in Kocas State Farm. 1. Milk yield traits. Türk J. Vet. Anim. Sci. 26: 97-101.

Erdem H, Atasever S, Kul E. 2007. Milk yield and fertility traits of Holstein cows raised at Gökhöyük State Farm 1. Milk yield traits. J. of Fac. of Agric. of OMU, 22(1): 41-46.

Gönül T. 1971. Researches on Different Milk Yield Recording and Calculation Methods in Cattle. Aegean Univ. Fac. Of Agriculture, Publication No: 177. Aegean University Press, Bornova / İzmir, Turkey.

Green LE, Schukken YH, Green MJ. 2006. On distinguishing cause and consequence: Do high somatic cell counts lead to lower milk yield or does high milk yield lead to lower somatic cell count? Preventive Veterinary Medicine 76: 74-89.

Gyawu P, Asare K, Karikari PK. 1990. The performance of imported Holstein Friesian cattle and their progeny in the humid tropics. Anim. Bred. Abst., 58: 2654.

Juozaitiene V, Juozaitis A. 2005. The influence of somatic cell count in milk on reproductive traits and production of Black and White cows. Vet. Arhiv., 407- 414.

Kaya I, Uzmay C, Kaya A, Akbaş Y. 2003. Comparative analysis of milk yield and reproductive traits of Holstein-Friesian cows born in Turkey or imported Italy and kept on farms under the Turkish-ANAFI Project. Italian Journal of Animal Science, 2(2): 141-150.

Koç A. 2001. Phenotypic and Genetic Parameters Estimation of Reproduction and Milk Yield of Holstein-Friesian Cows Raised in Dalaman State Farm. PhD Thesis, Graduate School of Natural and Applied Science, Adnan Menderes University, Aydın, Turkey.

Koç A. 2006a. Lactation milk yields and somatic cell counts of Holstein Friesian and Brown-Swiss cattle reared in Aydin province. Hayvansal Üretim, 47(2): 1-8.

Koç A. 2006b. Analysis of repeated milk somatic cell count of Holstein-Friesian cows raised in Mediterranean climatic conditions. J. of Biol. Sci., 6(6): 1093-1097.

Koç A. 2007a. A study on fat content, non-fat dry matter content and somatic cell count of Montbeliarde and Holstein-Friesian cows. Turkish Dairy Cattle Conference Proceeding, pp: 386394. 25-27 October, İzmir/Turkey.

Koç A. 2007b. Daily Milk Yield, Non-Fat Dry Matter Content and Somatic Cell Count of Holstein-Friesian and BrownSwiss Cows. Acta Vet. -Beograd, 57(5-6): 523-535.

Koç A. 2008a. Factors influencing daily yield, somatic cell count and non-fat dry matter content of milk. The Indian Veterinary Journal, 85: 630-632.

Koç A. 2008b. A study of somatic cell counts in the milk of Holstein-Friesian cows managed in Mediterranean climatic conditions. Türk. J. of Vet. Anim. Sci., 32(1): 13-18.

Koç A, Özdemir Z, Armağan G. 2009. A study on raw milk quality and affected factors produced in some dairy cattle farms in Aydın. (Poster). Pamukkale Milk and Dairy Products Symposium, 21-23 May, Kınıklı, Denizli, Turkey. 
Koç A. 2011. A study of the reproductive performance, milk yield, milk constituents, and somatic cell count of HolsteinFriesian and Montbeliarde cows. Turk. J. Vet. Anim. Sci., 35(5): 295-302.

Koç A, Akçay H, Yılmaz H. 2011. A study on different kind of production characteristics of Red Holstein cattle. 7. National Animal Science Conference. 14-16 Sep. Adana/Turkey.

Koç A. 2012. Short Communication. Effects of some environmental factors and extended calving interval on milk yield of Red Holstein cows. Spanish J. Agri. Res., 10(3): 717-721.

Koç A. 2015. Effects of somatic cell count and various environmental factors on milk yield and foremilk constituents of Red-Holstein cows. Tarım Bilimleri Dergisi, 21 (3): 439-447.

Koç A. 2016. A review on Simmental Raising: 2. Studies in Turkey. J. ADU Agri. Fac., 13(2): $103-112$.

Koç A. 2017a. A research on herd life of Holstein-Friesian, RedHolstein and Simmental cows. J. ADU Agri. Fac., 14(2): 63-68.

Koç A. 2017b. Effects of some environmental factors on milking time milk yield in Red Holstein cows. Turkish Journal of Agriculture-Food Science and Technology, 5(8): 917-922.

Koç A, Akaydın S, Çatıkkaş E. 2017. A study on herd life and milk quality of cows raised at some dairy cattle farms in Aydın. Scientific Project Unit Finishing Report, Adnan Menderes University, Aydın, Turkey.

Nenadovic M, Gavrilovic S, Vucinic J. 1987. The relationship of age at first calving with the performance of Yugoslav Pied cows. Anim. Breed. Abst., 45:5972.

Özçelik M, Arpacık R. 2000. The effect of lactation number on milk production and reproduction in Holstein cows. Turk $\mathrm{J}$. Vet. Anim. Sci, 24: 39-44.

Perez C, Buzzetti IG, Bama PN, Gonzalez MF. 1986. Milk yield characters in Holstein Friesian cows in the Metropolitan region of Chile. 1. Phenotypic characters and factors affecting variation. Anim. Bred. Abst., 54:2720.

SAS. 1999. Statistical Analysis System for Windows. (Relase 8.2). SAS Institute Inc. Raleigh, N. Caroline, USA.

Speignt BR, Fairlie BWG. 1987. The distribution of ages at first calving. Anim. Bred. Abst. 55:2092.

Şekerden Ö, Özkütük K, Pekel E. 1989. Milk and some yield characteristics of Holstein-Friesian cattle population in intensive dairy cattle farms in Amasya province. Ç. Ü. Zir. Fak. Derg., 4:56-66.

Türkyılmaz MK. 2005. Reproductive characteristics of Holstein cattle reared in a private dairy cattle enterprise in Aydın. Turk J. Vet. Anim. Sci. 1049-1052.

Uzmay C, Kaya A, Kaya I, Akbaş Y, Saçl1 Y. 1998. A comparative analysis of some production characteristic of Holstein Friesian cows born in Turkey or brought from Italy in Turkish-ANAFI Project conducted in Izmir, Manisa and Aydin provinces. Aegean Region 1. Agricultural Symposium. Vol. II. 7-11 Sep. Aydın, Turkey.

Yaylak E. 2003. Researches on Some Physiological and Morphological Traits of Holstein-Friesian Cows Raised in Farms with Pedigreed Studies in Odemis Region. PhD Thesis. School of Graduate and Applied Science, Aegean Univ., İzmir, Turkey.

Yilmaz H. 2010. A Study on Milk Yield and Milk Quality Traits of Red Holstein Cows. MSc. Thesis. Graduate School of Natural and Applied Science, Adnan Menderes Univ., Aydın, Turkey. 